\title{
Obituary*
}

\section{G. R. Hart}

Gillian R. Hart (Jill Hart), who made indispensable contributions to Anatolian, Mycenaean and Indo-European studies, died on 8th February 2004. She was born on I I th August 1934 in Eastbourne, Sussex, the elder of the two children of Alexander and Catherine Hart, who had a farm near Heathfield in the Sussex Weald. She inherited from her Lowland Scottish father, who had been an army international amateur heavyweight boxer, much of his size, strength and great determination. Her maternal grandmother was also Scottish, descended through her MacDonald family from the Lord of the Isles. Her mother's father, Sir Courthope Wilson, was Vice Chancellor of the Duchy of Lancaster, and her Aunt Dorothy had been only the second woman in England to become a Minister of Religion. Jill may have drawn some inspiration from this ancestry and from the high expectations of her parents. During the war the family moved to the New Forest, then Devon, and finally in I945, to another farm in South Oxfordshire, determined to find her good schools. While attending St Peter's Hill School and then the Abbey School, Reading (I947-53), she excelled in Latin and Greek, and after a year at Reading University entered Lady Margaret Hall, Oxford, to read Classics in 1954. Jill opted to offer a special subject in Greek and Latin Comparative Philology in addition to the traditional 'Greats' course consisting of Ancient History and Philosophy. This was followed by the Oxford two year postgraduate Diploma (now an M.Phil.) in Comparative Philology, where she studied Sanskrit under T. Burrow, and was supervised in Greek by L. R. Palmer.

Palmer was at this time much occupied with Mycenaean Greek, and Jill became thoroughly involved in this developing branch of philological scholarship. She assisted Palmer with his work for The Interpretation of Mycenaean Greek Texts (Oxford, I963) and her first independent publications and Mycenaean Seminar papers deal with both the content of Linear B Texts (1965) and their language and script (1966, I968, I973). For two decades Jill regularly contributed bibliographical data for Studies in Mycenaean Inscriptions and Dialects. Her early articles show not only even-handedness in noting all previous work on the topics in question, but an independence of approach and an uncompromisingly logical line of argument. She did not hesitate to question the opinions of well-established scholars such as G. Mylonas or those of her own teacher L. R. Palmer (to whom she often acknowledged a debt of gratitude for encouraging her to become a scholar). The same sort of self-reliance and intellectual courage was apparent in everything Jill wrote, said or did throughout her life.

After a year's teaching in Comparative Philology of Greek and Latin at Oxford (vice Palmer), Jill was appointed to a lectureship in Classics at the University College of Wales, Aberystwyth,

\footnotetext{
* I am grateful to Christopher Hart for the first paragraph and to Anna Morpurgo Davies, Eleanor Dickey, Philomen Probert, Michael Stokes, David Thomas, and Clifford Wright for other contributions and advice. 
a post which she held I960-69. During sabbatical leave (I966-67) she returned to Oxford to read for the Oriental Studies B.Phil. in Hittite under the supervision of O. R. Gurney, and this marked a turning point as from then on Hittite became the focus of her research interests. In her B.Phil. thesis on the Hittite particle -pat (published in TPS I97I) she established once and for all the phonological value, the syntax and the function of this problematic 'word', and demonstrated the futility of etymological speculations based on insufficient material.

During I970s and I980s there followed a series of papers devoted to Hittite linguistic questions, in which Jill insisted that the Hittite texts should not be regarded as a "homogeneous corpus" (I983:I27), but careful attention should be paid to the chronology of each document, whether it was an original or a copy of an earlier document, and even to the spelling habits of individual scribes. This method involved an enormous amount of painstaking groundwork, but as a result Jill was able to contribute to the identification and description of successive synchronic states of the language where previously scholars had only seen orthographic confusion. Her most important discoveries were about the class of Hittite 'nasal infix verbs', where she proved that -ni- alternates with -nin- as the result of an inner Hittite phonological development (I978); the regular association of 'plene-writing' (the writing of an extra vowel sign in one syllable of a word) in early Hittite texts with both nominal and verbal stems that show Ablaut alternations, and the indications that plenewriting represents a phonological effect of the inherited accent (BSOAS, I980); the original distinction between the Ablaut patterns shown by the present and preterite of Hittite radical verbs which follow the -mi conjugation, and the ways in which the earliest patterns were restructured by Hittite innovations (Anatolian Studies, 1980). Her TPS I983 article discussed the complex factors that determined the choices made by Hittite scribes among the signs that in Old Babylonian distinguished voiced and voiceless stops; it also argued that the signs $u$ and $u$ may have indicated distinct Hittite vowels, and demonstrated in exemplary fashion the importance of distinguishing spelling variations from phonological alternations. In all these publications there were discoveries of great significance for Indo-European historical reconstruction, but Jill hesitated to offer a full diachronic interpretation and merely pointed out how the newly assembled Hittite evidence supported or contradicted the currently accepted diachronic models. Her erudition in Hittite was such that she realised how much more work remained to be done, and how progress in diachronic questions could only proceed very gradually.

However, in the later I980s Jill started to tackle questions of prehistory herself, since she had come to feel, as did a number of scholars, that some features of Hittite, and particularly of the Hittite verb, called for far-reaching revisions to Proto Indo-European reconstructions based largely on Greek and Sanskrit. She did not take refuge in any sort of Indo-Hittite hypothesis (according to which the Anatolian family separated from the common ancestor language at a very much earlier date than the other branches of Indo-European), but in two articles in BSOAS (1988, I990) gave a highly original account of how the Indo-European middle, some common types of thematic present, and the subjunctive may have developed. Her views remain controversial, though not the evidence which she adduces, as it is clearly capable of many interpretations. 
While she was helping to establish the methodological foundations of present day Anatolian linguistic scholarship, Jill was also teaching the full range of courses demanded by a post in Classics at Durham University (I969-93). Successive Heads of Department regularly assigned her courses on literary topics in addition to linguistic ones, recognising not only her immense conscientiousness as a teacher, but also the breadth of her interests and many-sided abilities (which included her own poetry). In order to pursue her research on Hittite she spent every vacation and sabbatical in Oxford, where she maintained a second home, and for nearly 35 years she was a familiar figure (and a figure of imposing stature whom it was hard to miss!) in the Oxford Griffith Institute Library and the Oriental Institute. Although a very private person, and in many respects quite diffident, she enjoyed the conversation at coffee time in the Oriental Institute, and was always happy to talk about Sanskrit comparative evidence and Indo-European reconstruction, especially with her former teacher T. Burrow (the books Jill reviewed include many on Sanskrit historical linguistic topics, and BSOAS I987 contains her obituary notice for Burrow). As she was averse to travelling abroad she was not well known personally outside a fairly limited circle in the UK and one or two close friends from the USA who visited Oxford, but her publications on Hittite were respected internationally.

Jill started using computers as an aid to her work in advance of most academics in the Humanities and she was extremely excited by the possibilities they offered (for example, in her I983 paper they helped her to work out the relative frequencies of the signs TU/DU, TA/DA, KA/GA). At Durham she developed electronic programmes to assist the teaching of Greek and Latin language to Classics and Theology students. When Jill took early retirement in I993, and settled permanently in Oxford, her knowledge of hardware and software was put to use by the Faculty of Oriental Studies where she coordinated IT before the University invented posts in IT Support.

Although she gave some papers at Oxford Comparative Philology Seminars and became much loved by the Oxford graduate students in Comparative Philology whom she met at Philological Lunches, Jill's scholarly plans for her retirement were sadly never realised: in I996 her eyesight started to deteriorate and she became increasingly limited by ill-health. Nevertheless she continued to read new publications, to write a further book review, and to work on another paper. This paper (published posthumously in 2004) again shows Jill's remarkable originality and ingenuity in finding solutions to historical linguistic problems: a small puzzling group of words where a Hittite sibilant corresponds to a Luwian dental sound can be accounted for, she argued, if $\mathrm{IE}^{*} H_{3}$ underwent a conditioned change near $/ u /$ and $/ w /$ in Anatolian (for instance, Hittite šăkuwa, Luwian da-a-u-wa 'eyes' are cognates, and are also related to words for 'eyes' in other Indo-European languages).

During these final years Jill also taught Hittite. Her students were amazed by the way in which she had memorised whole Hittite texts and could still discuss them in minute detail. Jill was at her happiest when helping younger people, and her learning, her generosity, and her quiet but sometimes rather wicked sense of humour were above all appreciated by her students and the younger scholars who were fortunate enough to know her.

ELIZABeth Tucker

The Oriental Institute, University of Oxford 


\section{Articles}

\section{5}

'The Grouping of Place-Names in the Knossos Tablets', Mnemosyne, Series 4, vol. I8, I965, I-28.

\section{6}

'The Effects of the Palatalization of Plosives in Mycenaean Greek', in J. Chadwick and L. R. Palmer (eds.), Proceedings of the Cambridge Colloquium on Mycenaean Studies. Cambridge I966, I28-I 34 .

\section{8}

'Some recent work on early Greek phonology' (Summary of a Paper Read at the Mycenaean Seminar, University of London, May 1968), Bulletin of the Institute of Classical Studies I 5 , I968, I 44 .

1969

'The Hittite and Luwian Decipherment Theories [of Linear A]' (Summary of a paper read at the first conference of the British Association for Mycenaean Studies, September I968), Bulletin of the Institute of Classical Studies, University of London, I6, I969, I66-67.

I97I

'The Hittite particle -pat', Transactions of the Philological Society I97I [I973], 94-I62.

\section{I973}

'Linear B and Neutralization: A structural coincidence?, Kadmos I2, I973, 95-99.

I976

'Hittite hi-ni-ik-ta'. In A. Morpurgo Davies and W. Meid (eds.), Studies in Greek, Italic and Indo-European Linguistics offered to Leonard R. Palmer on the occasion of his seventieth Birthday. Innsbruck 1976. 93-6.

1978

'On the origin of Hittite nasal infix verbs of the type sarnikzi, sarninkanzi', Archivum Linguisticum 8, I978, I33-4I.

\section{I980}

'Some observations on plene-writing in Hittite', Bulletin of the School of Oriental and African Studies 43, I980, I-I7.

'The Ablaut of Present and Preterite in Hittite radical verbs', Anatolian Studies 30, I980, $5 \mathrm{I}-6 \mathrm{I}$.

\section{I98I}

'KUB XXXI Iог L 25: paittani or kuittani?', Kadmos 20, I98 I, I I9-I2 I.

\section{I983}

'Problems of writing and phonology in cuneiform Hittite', Transactions of the Philological Society I983, IOO-I 54 . 
1986

'Computer-assisted learning of a classical language at Durham', The CTISS File 2, I986, I 8-I9.

1987

'On the Greek secondary ending of the I sg. middle'. In J. T. Killen, J.-P. Olivier and J. L. Melena (eds.), Studies in Mycenaean and Classical Greek presented to John Chadwick = Minos 20-22, I987, 22 I-226.

'Computer-assisted learning of elementary Greek at Durham: the first two years', SESAME Bulletin: Language Automation worldwide I (part 4), I987 [1988], 72-82.

'Obituary. Thomas Burrow', BSOAS 50, I987, 347-357.

1988

'Anatolian evidence and the origins of the Indo-European mediopassive', Bulletin of the School of Oriental and African Studies 51, I988, 69-95.

1990

'Class I Present', subjunctive and middle voice in Indo-European', Bulletin of the School of Oriental and African Studies 53, I990, 446-68.

\section{4}

'Mycenaean se-re-mo-ka-ra-a-pi and se-re-mo-ka-ra-o-re'. Minos N.S. 25-26, I990-I99I [1994], 3 I9-29.

\section{4}

'Some Problems in Anatolian Phonology and Etymology'. In. J. H. W. Penney (ed.), IndoEuropean Perspectives. Studies in Honour of Anna Morpurgo Davies. OUP 2004. 34I-354.

\section{Reviews and Notices}

JRS LXV, 1975, 240-I. Review of W. S. Allen, Accent and Rhythm: Prosodic Features of Latin and Greek (Cambridge, I973).

JHS 97, I977, 212. Review of T. G. Spyropoulos and J. Chadwick, The Thebes Tablets II (Salamanca, I975).

Kratylos 28, I983 [1984], I02-I08: Review of N. Oettinger, Die Stammbildung des hethitischen Verbums (Nürnberg, I979).

The Classical Review XXXIII, I983, 342-43: Review of M. Peters, Untersuchungen zur Vertretung der indogermanischen Laryngale im Griechischen (Vienna, I980).

The Classical Review XXXIV, I984, I40-4I. Review of J. Haudry, Préhistoire de la flexion nominale indo-européenne (Lyon, I982).

The Classiclal Review XXXV, 1985, 2 I 3-I4: Review of A. Heubeck and G. Neumann (eds.), Res Mycenaeae. Akten des VII Mykenologischen Colloquiums in Nürnberg vom 6-10 April 1981 (Göttingen, 1983). 
JRAS I988, 439-40: Review of B. Tikkanen, The Sanskrit Gerund: A Synchronic, Diachronic and Typological Analysis (Helsinki, 1987).

JRAS I988, 440-442. Review of T. Gotō, Die 'I Präsensklasse' im Vedischen: Untersuchungen der Vollstufigen Thematischen Wurzelpräsentia (Vienna, 1987).

JRAS I990, I78-8I. Review of A. Lubotsky. The System of Nominal Accentuation in Sanskrit and Proto-Indo-European (Leiden, I988).

The Classical Review XL, I990, 84-86: Review of E. J. Bakker, Linguistics and Formulas in Homer: Scalarity and the Description of the Particle per (Amsterdam and Philadelphia, I988).

The Classical Review XL, I990, 334-35: Review of D. J. Taylor (ed.), The History of Linguistics in the Classical Period (Amsterdam and Philadelphia, 1987).

The Classical Review XL, I990, 335-37: Review of G. Calboli (ed.), Subordination and Other Topics in Latin: Proceeedings of the Third Colloquium on Latin Linguistics (Amsterdam and Philadelphia, 1989).

The Classical Review XLI, I99I, I29-30: Review of O. Szemerényi, An den Quellen des lateinischen Wortschatzes (Innsbruck, I989).

The Classical Review XLII, I992, 96-97: Review of B. Jaquinod, Le Double accusatif en grec d'Homère à la fin du V siècle avant J.-C. (Louvain-la-Neuve, I989).

BSOAS 55, I992, 346-47. Review of A. Breunis, The nominal sentence in Sanskrit and Middle Indo-Aryan. (Leiden, I990).

BSOAS 55, I992, I38-39. Review of K. Yoshida, The Hittite Mediopassive Endings in -ri (Berlin and New York, I990).

The Classical Review XLII, I992, 353-55: Review of R. Coleman, New Studies in Latin Linguistics. Selected Papers from the 4th International Colloquium on Latin Linguistics, Cambridge, April 1992. (Amsterdam and Philadelphia, I99I).

The Classical Review XLIII, I993, I9I: Review of N. Deplazes: Der griechische Dativ Plural und oblique Dual untersucht anhand des ältesten inschriftlichen Materials sowie ausgewählter Literatur (Bern, I99I).

The Classical Review XLIII, I993, I93-94: Review of A. Potthoff, Lateinische Kleidungsbezeichnungen in synchroner und diachroner Sicht (Innsbruck, I992).

JRAS I994, 452-454. Review of M. M. Deshpande, Sanskrit and Prakrit: sociolinguistic issues (Delhi, I993).

BSOAS 62, I999, 553-54. Review of A. Prins, Hittite Neuter Singular - Neuter Plural: some evidence for a connection (Leiden, I997). 